\title{
G.A. GERASIMENKO: BREAKS OF FATE AND CREATIVITY OF THE HISTORIAN
}

\author{
Petr S. Kabytov \\ Samara National Research University, Samara, Russian Federation \\ Nadezhda N. Kabytova \\ Samara National Research University, Samara, Russian Federation \\ Ekaterina P. Barinova \\ Samara National Research University, Samara, Russian Federation
}

\begin{abstract}
Introduction. Currently, interest in studying the creative heritage of prominent Russian historians has increased significantly, the formation of conceptual views of which took place under the conditions of the dominance of the Marxist-Leninist methodology. Such researchers include Honored Scientist of the Russian Federation, Doctor of Historical Sciences, Professor Grigory Alekseevich Gerasimenko. His scientific heritage is widely and highly appreciated by specialists. Methods and materials. The fate and scientific work of the scientist was recreated on the basis of the works published by him, reviews of them, attraction of memoirs, bibliographic reference books and some documentary materials on the basis of which his works were created. In this article, on the basis of the anthropological method, the problems of scientific research by G.A. Gerasimenko at different periods of his life and work are analyzed; the principles and methods of research practices of the scientist are considered. Analysis. The first stage of scientific and pedagogical activity of the scientist is connected with the Saratov State University named after N.G. Chernyshevsky, where he studied, then taught at the Faculty of History and created his scientific works. They present observations and conclusions about the party-political struggle in the councils of workers' and soldiers' deputies of the Volga region; on the basis of mass historical sources, the forms and methods of organizing peasant committees in 1917 were shown, the dynamics of their social composition were revealed. These definitions conditioned the historian's contribution to the study of the topical issues of the Great Russian Revolution. The article shows the expansion of the chronological and territorial framework of research by G.A. Gerasimenko during the Moscow period of his scientific activity. He turned to identifying the prerequisites for radical actions of peasants, revealed the causes of conflicts between the people and the authorities, and outlined the positions of public organizations during the revolution. Results. Analyzing the work of the historian, the authors revealed traditions and innovations in his work, noted new methodological techniques and - historiographic plots in the scientist's creative laboratory.

Key words: historical science, G.A. Gerasimenko, councils, committees, zemstvos, commissars of the Provisional Government, establishment of Soviet power, methodology and methods of research.

Citation. Kabytov P.S., Kabytova N.N., Barinova E.P. G.A. Gerasimenko: Breaks of Fate and Creativity of the Historian. Vestnik Volgogradskogo gosudarstvennogo universiteta. Seriya 4. Istoriya. Regionovedenie. Mezhdunarodnye otnosheniya [Science Journal of Volgograd State University. History. Area Studies. International Relations], 2021, vol. 26, no. 5, pp. 232-244. (in Russian). DOI: https://doi.org/10.15688/jvolsu4.2021.5.19
\end{abstract}




\title{
Г.А. ГЕРАСИМЕНКО: ИЗЛОМЫ СУДЬБЫ И ТВОРЧЕСТВА ИСТОРИКА
}

\author{
Петр Серафимович Кабытов \\ Самарский национальный исследовательский университет им. академика С.П. Королева, \\ г. Самара, Российская Федерация

\section{Надежда Николаевна Кабытова} \\ Самарский национальный исследовательский университет им. академика С.П. Королева, \\ г. Самара, Российская Федерация
}

\section{Екатерина Петровна Баринова}

Самарский национальный исследовательский университет им. академика С.П. Королева, г. Самара, Российская Федерация

\begin{abstract}
Аннотация. В настоящее время существенно возрос интерес к изучению творческого наследия видных российских историков, формирование концептуальных взглядов которых происходило в условиях господства марксистско-ленинской методологии. К числу таких исследователей относится Заслуженный деятель науки Российской Федерации, доктор исторических наук, профессор Григорий Алексеевич Герасименко. Его научное наследие обширно и высоко оценено специалистами. Судьба и научное творчество ученого воссозданы на основе опубликованных им произведений, рецензий на них, привлеченных воспоминаний, библиографических справочников и некоторых документальных материалов, на базе которых создавались его труды. В данной статье на основе антропологического метода анализируется проблематика научных изысканий Г.А. Герасименко в разные периоды его жизни и творчества; рассматриваются принципы и методы исследовательских практик ученого. Первый этап научно-педагогической деятельности ученого связан с Саратовским государственным университетом имени Н.Г. Чернышевского, где он учился, затем преподавал на историческом факультете и создавал свои научные труды. В них представлены наблюдения и выводы о партийнополитической борьбе в советах рабочих и солдатских депутатов Поволжья; на основе массовых исторических источников показаны формы и методы организации крестьянских комитетов в 1917 г., выявлена динамика их социального состава. Эти определения обусловили вклад историка в изучение актуальной проблематики Великой российской революции. В статье показано расширение хронологических и территориальных рамок исследований Г.А. Герасименко в московский период его научной деятельности. Он обратился к выявлению предпосылок радикальных действий крестьян, выявил причины конфликтов между народом и властью, обозначил позиции общественных организаций в ходе революции. Выявляя традиции и новации в творчестве историка, авторы отметили его обращение к историографическим и методологическим проблемам. Вклад авторов: П.С. Кабытов осуществил общий замысел статьи и аналитическую обработку текста, рассмотрел саратовский период жизни и деятельности Г.А. Герасименко; Н.Н. Кабытова сформулировала концептуальные положения, характеризующие вклад ученого в изучение деятельности земств, комитетов, губернских и уездных комиссаров Временного правительства; Е.П. Баринова проанализировала эволюцию взглядов Г.А. Герасименко в московский период научного творчества, составила библиографический список.
\end{abstract}

Ключевые слова: историческая наука, Г.А. Герасименко, советы, комитеты, земства, комиссары Временного правительства, установление советской власти, методология и методы исследования.

Цитирование. Кабытов П. С., Кабытова Н. Н., Баринова Е. П. Г.А. Герасименко: изломы судьбы и творчества историка // Вестник Волгоградского государственного университета. Серия 4, История. Регионоведение. Международные отношения. - 2021. - Т. 26, № 5. - C. 232-244. - DOI: https://doi.org/10.15688/jvolsu4.2021.5.19

Введение. В 2021 г. исполняется 90 лет со дня рождения видного российского историка, Заслуженного деятеля науки Российской Федерации, доктора исторических наук, профессора Григория Алексеевича Герасименко. В его жизни и научно-педагогической деятельности отразились все важнейшие события новейшей отечественной истории. Они 
оказали мощное воздействие на формирование мировоззрения историка. Неуемная энергия, целеустремленность, настойчивость и инициатива позволили ему внести значительный вклад в изучение истории Великой российской революции. Г.А. Герасименко прожил яркую жизнь, в которой были крутые повороты, но он всегда успешно преодолевал встречавшиеся на его пути препятствия. Он был истинный трудоголик: кропотливо изучал научные труды предшественников, неутомимо работал в центральных и региональных архивах, выявил огромный массив информационного материала о революционных событиях в периодических изданиях за 1917 год.

До недавнего времени жизни и творческому пути Г.А. Герасименко было посвящено всего несколько скупых строчек в энциклопедии Саратовского края и Большой биографической энциклопедии. Некоторые труды историка стали объектом анализа в рецензиях и историографических обзорах $[19 ; 24 ; 29 ; 30]$. Лишь после его безвременной кончины появились исследования, в которых были воссозданы вехи жизненного пути [21], основные этапы научно-педагогической деятельности [22; 23], реконструирована творческая лаборатория ученого [20]. Однако вклад Г.А. Герасименко в разработку проблем социально-политической истории России эпохи войн и революции начала XX века представлен недостаточно.

Цель данной статьи состоит в том, чтобы оценить вклад Г.А. Герасименко в разработку теоретико-методологических и конкретно-исторических сюжетов, освещающих разнообразную проблематику Великой российской революции. Для этого сформулированы следующие задачи: 1) рассмотреть проблематику сочинений автора; 2) показать эволюцию его взглядов; 3 ) выявить исследовательские методы и принципы историка. Научное наследие историка составляет источниковую базу данной статьи. Оно включает более 100 трудов, из них 18 монографий и множество статей, в которых были поставлены и исследованы актуальные вопросы, характеризующие специфику российского революционаризма. Сформулированные задачи решаются последовательно на основе анализа научных трудов Г.А. Герасименко в саратовский и московский периоды его жизни.
Методы и материалы. Методологические принципы изучения революции имеют особое значение для выявления ее характера, движущих сил и результатов. Анализируя вклад Г.А. Герасименко в рассмотрение комплексной проблемы - Великая российская революция - авторы использовали приемы и процедуры, позволяющие решить поставленные задачи. В качестве базового был выделен принцип историзма, позволяющий изучить творческий путь ученого в конкретно-историческом контексте. При этом учитывались многофакторные процессы объективного и субъективного свойства: социально-экономическое, идейно-политическое, психологическое состояние общества, в котором жил и творил историк. В связи с этим определяющим стал культурно-антропологический подход, на основе которого были реконструированы в динамике ценностные установки, пронизывающие жизнь и творчество Г.А. Герасименко. Названные принципы определили исследовательские методы: дискретный (был применен для отображения особенностей жизненного пути историка); компаративный (использовался для выявления сходства и различий между методологическими принципами в историографии советского и постсоветского периодов); историкобиографический (предполагающий воссоздание биографии Г.А. Герасименко на фоне реконструкции типичного жизненного пути ученого в области гуманитарных наук); социопсихологический анализ (применялся как вспомогательный - для объяснения поведенческой практики ученого в меняющихся обстоятельствах общественного и личного характера).

Анализ. Григорий Алексеевич Герасименко (19.08.1931-13.08.2005) родился в крестьянской семье на Дальнем Востоке. По окончании средней школы он приобрел первый педагогический опыт преподавания в Климовской сельской школе, а затем, после обучения в Челябинском летном училище, принимал участие в военном конфликте 1950-1953 гг. на Корейском полуострове. После демобилизации по ранению из рядов Советской армии связал свою судьбу с Саратовским государственным университетом, где с 1954 г. он последовательно был студентом, аспирантом, ассистентом, доцентом, профессором, деканом исторического факультета. 
Саратовский период. Его кандидатская диссертация была посвящена рассмотрению особенностей установления советской власти в губерниях и уездных центрах через призму партийно-политической борьбы в советах Нижнего Поволжья [11; 13]. Методология его исследования соответствовала официальным постулатам советских историков, стремившихся доказать наличие союза рабочего класса и беднейшего крестьянства под руководством большевиков, победивших в революции. Изучение процесса возникновения и деятельности советов тесно связывалось с такими критериями: численность промышленных пролетариев в губернских и уездных центрах, наличие и активность большевистских организаций в губернских городах, отдельных групп большевиков и их представителей в сельской местности.

Всеэти вопросы находились в центре внимания Поволжского регионального объединения Научного совета АН СССР по проблеме «Великая Октябрьская социалистическая революция», которое в 1967 г. подготовило коллективную монографию [28]. В сборе необходимых материалов оказывали помощь авторам и редколлегии многие ученые, среди которых был Г.А. Герасименко [11, с. 14].

Расширяя источниковую базу своих исследований, Г.А. Герасименко подчеркивал роль солдат в процессе создания и функционирования советов. Он выделял размежевание политических сил в офицерской и солдатской среде, которое завершилось созданием самостоятельных советов солдатских депутатов. Детально рассмотрев процесс их создания и показав особенности слияния их с советами солдатских депутатов, исследователь отметил успешную тактику большевиков, оттеснивших на второй план меньшевиков и эсеров [13], что явилось решающим фактором в процессе установлении советской власти.

Работая в областных архивах Нижнего Поволжья, Г.А. Герасименко обнаружил массив опросных листов, в которых содержалась обширная информация о времени создания волостных советов и их деятельности. Всего им был выявлен 231 документ, которые были подготовлены к V губернскому крестьянскому съезду. Изучив эти материалы, он высоко оценил их информативную значимость для реконструкции процесса создания Советов крестьянских депутатов [6, с. 50]. Одновременно в докторской диссертации, Г.А. Герасименко сформулировал новую задачу: установить социальный состав сельского населения в низовых советах 1917 г. и выявить, как он изменился к лету 1918 г. [10, с. 33].

В результате нового прочтения массовых источников историк показал масштабы и направленность выступлений крестьян против помещиков, частных владельцев и землеустроенных крестьян. В центре его внимания оказались также земельные комитеты, которые, по мнению исследователя, внесли организующее начало в массовое крестьянское движение [10, с. 164]. В отличие от предшественников Г.А. Герасименко по-новому подошел к участию солдат в организации протестных выступлений в деревне. Он отметил, что если летом 1917 г. низовые крестьянские организации брали на учет помещичьи хозяйства и составляли описи имущества, то осенью стало увеличиваться число разгромов и разграблений частновладельческих владений [10, c. 172, 175]. В освещении процесса создания волостных земств в Нижнем Поволжье автор придерживался традиционных подходов. Он считал, что на смену низовым крестьянским организациям «пришли антидемократические, в основной массе кулацкие, правоэсеровские волостные земские управы, которые своей консервативной, охранительной деятельностью оттолкнули от себя трудовое крестьянство, тем самым лишились его доверия и поддержки и ослабили организующее начало в крестьянском движении» $[10$, с. 213]. Заметим, кстати, что с формальной точки зрения земства были демократичнее комитетов. Таким образом, в монографии Г.А. Герасименко был поставлен и в значительной степени по-новому решен комплекс проблем, возникших в ходе аграрной революции. Он стремился на основе анализа массовых источников показать роль низовых крестьянских организаций. Эта монография была высоко оценена научной общественностью и в 1978 г. опубликована в США [32].

В 1970-е гг., возвращаясь к истории советов, Г.А. Герасименко развивает концептуальные положения, характеризующие их место и 
роль в революции. В совместной с Ф.А. Рашитовым монографии он рассмотрел методы борьбы советов за государственную власть [15]. В обозначенной работе раскрывается своеобразие установления советской власти не только в губернских, но и в уездных городах. Авторы обращают внимание на необходимость изучения способов организации волостных и сельских советов. Различные аспекты партийно-политической борьбы в советах всегда привлекали исследователей. Для характеристики эволюции программных установок и тактики политических партий в революции в работе Г.А. Герасименко и Д.С. Точеный использовали многофакторный подход [16]. В своей совместной монографии они обобщили локальные исследования, характеризующие особенности установления советской власти в Поволжье. Конечно, и здесь авторы остались верны трактовкам официальной советской историографии, но громадный фактический материал невольно побуждал исследователей к изменению парадигмы революционного процесса в России.

Изыскания Г.А. Герасименко о месте и роли советов в 1917 г. были хорошо фундированы, отличались новизной в постановке проблемных вопросов. В научном сообществе он был признанным специалистом. Рассматривая эволюцию советов от общественных объединений революционных потоков до органов власти, Г.А. Герасименко обратил внимание на генетическую связь советов рабочих и солдатских депутатов с низовыми крестьянскими комитетами. Новая книга В.В. Васькина и Г.А. Герасименко была посвящена истокам зарождения инициативных общественных объединений в ходе Февральского революционного переворота [3]. Реконструируя процесс ликвидации коронной администрации, авторы выявили роль солдат тыловых гарнизонов, прямо или опосредованно влиявших на ход революции не только в столице, но и в провинции [3, с. 37]. Они показали их участие в общедемократическом процессе: организации профсоюзов и фабзавкомов, разработке положения о милиции, введении на предприятиях восьмичасового рабочего дня и создания на них примирительных камер [3, с. 107]. В данной работе описаны три формы выборов волостных исполнительных комитетов: 1) избра- ние представителей на сельских сходах; 2) формирование их состава из членов сельских комитетов; 3) выборы депутатов на волостном сходе [3, с. 165].

Развивая проблему участия крестьян в революции, Г.А. Герасименко логично ставит задачу определить их роль в создании советского государственного аппарата на сельском уровне. Вместе со свои учеником В.П. Семьяниновым он обращается к рассмотрению важнейшей проблемы - социализации советской власти в крестьянской среде [14]. В ходе многочисленных дискуссий о характере и движущих силах революции данная проблематика имеет особое значение - выяснить, решался ли вопрос о том, какие категории крестьян поддерживали советскую власть и почему? В монографии Г.А. Герасименко и В.П. Семьянинова впервые предпринята попытка на конкретно-историческом материале Поволжья, отличавшегося многонациональным составом населения и различным уровнем развития капитализма в деревне, рассмотреть социальный состав и характер деятельности низовых крестьянских советов первого созыва, определить их место и роль в новой государственной системе. В своих наблюдениях и выводах авторы опираются прежде всего на первичные документы советов (анкеты, опросные листы, протоколы, отчеты ответственных работников и агитаторов), многие из которых вводились в научный оборот впервые. Обработка массовых источников позволила им аргументированно решить вопрос о социальном составе и характере деятельности низовых советов крестьянских депутатов в Поволжье. Авторы подчеркнули заинтересованность всех категорий крестьян в создании советов. Отмечая негативное отношение земств к советской власти, авторы солидаризировались с ленинской оценкой их буржуазной сущности [14, с. 20].

Г.А. Герасименко и В.П. Семьянинов уточнили время массового создания волостных советов в губерниях Поволжья (ими выявлены сроки создания 830 волостных советов) $[14$, с. 60$]$, анализируя при этом особенности социально-экономического развития региона, деятельность большевистских организаций, позиции эсеров. При всем многообразии структурных подразделений и норм представительства в советах, отмечают ав- 
торы, в целом низовой аппарат советской власти мог вполне квалифицированно осуществлять политические, административно-хозяйственные, культурно-просветительные функции [14, с. 77]. Это утверждение основано на избирательном подходе к историческим источникам. Управленческая деятельность волисполкомов была неэффективной из-за низкоквалифицированных кадров и ошибок центрального руководства.

Подробно анализируется в монографии участие волостных Советов в аграрных преобразованиях. Авторы выделяли две стадии в процессе ликвидации имений. На первой, когда этим занимались земельные комитеты и земства, в дележе могли участвовать все жители, предпочтение беднякам не отдавалось, поэтому большая часть имущества досталась зажиточным. На второй стадии распределение помещичьего имущества в Поволжье взяли в свои руки советы, которые прежде всего учитывали интересы бедняков и середняков. В исследовании утверждается, что в ходе перераспределения земель позиции сельской буржуазии оказались подорванными, по капиталистическим отношениям в деревне был нанесен сильный удар. Невольно авторы признали разрушительный характер политики советской власти в деревне. Рассматривая принципы формирования отрядов сельской Красной гвардии, авторы сами себе противоречат. С одной стороны, они заявляют, что данные формирования создавались для защиты советской власти от помещиков и буржуазии, а с другой утверждают, что они создавались там, где чаще всего вспыхивали кулацкие мятежи и где уезды подвергались нападению казачьих банд. Заметим, что никакие помещики и капиталисты в крестьянских восстаниях не участвовали. В книге предпринята попытка выявить причины неудач в продовольственной политике советской власти первой половины 1918 года. Однако объективные и субъективные обстоятельства здесь не разграничены. Не выявлены принципы и методы руководства низовыми советами со стороны большевистских организаций. Почти отсутствуют сведения о создании и деятельности сельских советов.

Московский период. Новый этап в жизни, преподавательской и научной деятельнос- ти Г.А. Герасименко начался с переездом в Москву. В 1980-2005 гг. он трудился в Высшей комсомольской школе, затем в Академии общественных наук, где заведовал кафедрами истории. Существенно расширились проблематика и территориальные границы его исследований. Он опубликовал серию статей в академических журналах «Вопросы истории» и «История СССР» (позднее последний стал именоваться «Отечественная история»; в настоящее время - «Российская история»).

В период перестройки усилились дезинтеграционные процессы в СССР. Г.А. Герасименко совместно с профессорами О. Обичкиным и Б. Поповым написал статью в газету «Правда», в которой был дан анализ пьесы М. Шатрова «Дальше, дальше, дальше...». Григорий Алексеевич, как истинный гражданин и патриот своей страны, отстаивал идеи содружества наций и народностей в едином Советском государстве.

Как известно, во второй половине 1980-х гг. советская историческая наука переживала кризис. О причинах этого явления и о ситуации, сложившейся на историческом фронте в советский период, Г.А. Герасименко попытался рассказать в статье «Без вины виноватые», которая была опубликована в «Литературной газете» в ноябре 1989 года. Автор призвал к консолидации писателей и историков, наивно полагая, что совместные усилия интеллектуальной элиты помогут преодолеть идеологический тупик и коллапс в исторических изысканиях [4].

В московский период жизни и творчества у Г.А. Герасименко появились новые коммуникативные практики. Он активно включился в деятельность ведущих научных школ, исследовавших предпосылки, специфику, результаты и последствия Великой российской революции. Неограниченные возможности работать в центральных государственных архивах он использовал для пополнения источниковой базы, расширяя диапазон проблематики своих научных изысканий. Участвуя в дискуссиях о характере аграрного строя в России начала XX века, Г.А. Герасименко обратил внимание на односторонне представленные в историографии способы и методы социализации аграрной политики самодержавия. Его новая монография, в которой раскрывались формы 
и методы противодействия крестьян столыпинской земельной реформе, была опубликована издательством Саратовского университета в 1985 г. [5]. В отличие от прежних исследований, которые имели региональный характер, в данной работе анализировалось крестьянское движение в губерниях Европейской России.

Г.А. Герасименко проделал огромную работу по изучению документальных публикаций, а затем по выявлению огромного массива архивных документов, материалов центральных и региональных периодических изданий. Это исследование появилось на сломе двух эпох. С одной стороны, в советской историографии доминировали принципы и методы марксистско-ленинской методологии, а с другой, явно наметились новые подходы в изучении аграрной истории России. В данном исследовании нашли отражение обе тенденции. Так, автор монографии, вслед за многими советскими историками, утверждал, что аграрная политика царизма провалилась [5, c. 341]. Он традиционно считал, что она привела к дальнейшему обезземеливанию и разорению крестьян [5, с. 324], отмечал обострение социальных противоречий внутри крестьянства, заявляя о наличии второй социальной войны в деревне [5, с. 5]. Однако это были реалии революции, а не реформаторского процесса. Анонсируя анализ оппозиционных настроений в деревне в связи с принятием указа 9 ноября 1906 г., сам же автор заявлял о том, что нет точных статистических данных об оппозиционных настроениях в обществе [5, с. 29].

Рассматривая роль властных структур в проведении реформы, Г.А. Герасименко показал отношение крестьян к землеустроительным комиссиям, раскрыл формы противодействия крестьян проведению в жизнь новой имперской аграрной политики. Ярко и эмоционально выглядит воссозданная историком картина, которая дает представление о взаимоотношениях общинников и выделенцев. В работе показано, какие приемы и методы использовали сельские сходы, пытаясь спасти крестьянский мир от разрушения, конкретными примерами подтвержден тезис об обострении противоречий между общинниками и выделенцами [5, с. 252]. Научную значимость не потерял и вывод Герасименко о том, что покидая общину, отрубщики и хуторяне теряли возможность влиять на решения сельских сходов и волостных собраний [5, с. 333]. Это подталкивало П.А. Столыпина к инициированию введения в Российской империи института волостного земства. Данная идея не нашла поддержки в Госсовете, но пользовалась популярностью в либеральных общественных кругах. К числу несомненных достоинств проделанной Г.А. Герасименко работы следует также отнести скрупулезный подсчет количества крестьянских выступлений, что позволило представить реальные масштабы протестных акций в ходе реализации реформы. В конечном итоге он пришел к выводу о том, что большинство сельского населения по инерции продолжало видеть в общине защитника своих интересов и отстаивать традиционный образ жизни.

Анализируя региональные аспекты революционных событий, Г.А. Герасименко обратил внимание на специфику институционных коллизий в российской провинции. Для этого он обратился к проблеме эволюции земских учреждений и специфике их деятельности в революционных условиях. Анализируя исследования дореволюционных российских историков, оценивая выводы американских русистов [34], Г.А. Герасименко отметил своеобразную конвергенцию их взглядов на земства как на внеклассовые структуры управления. В связи с этим, вполне в русле советской историографии, он стремился развенчать сложившийся стереотип об идеальной модели земского самоуправления. Характеристика дореволюционного земства понадобилась ему для обоснования концептуального вывода о неэффективности земской модели управления в системе власти на местах. Определяя место земств в революции, он заметил, что в ходе «перерастания буржуазно-демократической революции в социалистическую земства являлись серьезной политической силой... выше становился накал классовой борьбы... острее становилась борьба за власть на местах» [7, c. 4]. Исследование места и роли земств в революции было попыткой выйти за пределы марксистско-ленинских ограничительных установок. Автор отмечает, что «без воссоздания истории земских учреждений картина рас- 
пространения советской власти по стране останется односторонней, неполной», - отметил автор [7, с. 4]. Данная монография основательно фундирована. Она основана на документах не только центральных, но и областных государственных архивов, материалах периодической печати. Весьма ценным являлось использование в работе эго-документов, авторами которых были рабочие, крестьяне и солдаты. «Именно они придают колорит эпохе и заслуживают особого доверия», - подчеркнул исследователь [7, с. 51].

Вопросы о причинах краха земских учреждений в России являются дискуссионными среди историков, правоведов и политологов. Американский исследователь У. Розенберг считал, что земства рухнули из-за темноты, невежества и консерватизма крестьян, их враждебности к либерально-конституционным преобразованиям [33]. Г.А. Герасименко еще по инерции полагал, что главная причина краха земского самоуправления заключалась в его буржуазном характере, не изменившимся и после реформы Временного правительства. По его утверждению борьба между советами и органами местного самоуправления непосредственно отражала противоборство рабочего класса и крестьянства с буржуазией [7, с. 166]. Одновременно он доказывал, что земства в 1917 г. активно демократизировали свой состав [7, с. 166]. Подобного рода противоречия способствовали расширению проблематики в изучении специфики революционных событий на местах, рассмотрению властных альтернатив в 1917 г. [25]. Некоторые авторы в условиях постсоветского безвременья стали обвинять большевиков в разрушении земских учреждений [26]. Авторы данной статьи разделяют точку зрения японского исследователя Кимитака Мацузато, который считает, что механизм разрушения земства запустило Временное правительство, сделав его своим адептом [27]. Истина как всегда не в полярных оценках явления. Оно объясняется комплексом объективных и субъективных обстоятельств.

Детально изучив деятельность советов, общественных исполнительных комитетов, низовых крестьянских организаций, земских учреждений, Г.А. Герасименко - вдумчивый и скрупулезный ученый - вполне логично об- ратил внимание на необходимость выявить роль официальных властных структур на местах. Административное управление Временное правительство осуществляло через губернских и уездных комиссаров. Этот институт длительное время специально не рассматривался: в отечественной историографии - по идеологическим соображениям, а в зарубежной - из-за ограниченности источниковой базы. Две новые книги Г.А. Герасименко, вышедшие в постсоветский период, были посвящены особенностям государственного строительства в 1917 г., взаимоотношениям власти и общества в условиях революции. Вопросы демократизации власти, формирования гражданского общества были рассмотрены им на примере формирования и деятельности общественных исполнительных комитетов в 1917 г. [12]. Вслед за этим он исследовал формы и методы социализации временной власти, отметив ее неспособность решать насущные требования революционных потоков [9].

Размышления Г.А. Герасименко о характере временной власти в революционной России привели к необходимости изучения политических лидеров в революции. Группа исследователей - М.И. Басманов, Г.А. Герасименко и К.В. Гусев - обратились прежде всего к характеристике лидера либерально-демократических преобразований А.Ф. Керенского [1]. Г.А. Герасименко в книге принадлежат главы, описывающие поведенческие практики сначала министра юстиции, а затем премьер-министра Временного правительства. Образно и ярко автор показал восхождение Керенского на властный олимп, его истеричные метания в условиях нараставшего кризиса, интуицию и изворотливость в противоборстве сначала с правой, затем с левой оппозициями. Сюжеты, характеризующие судьбу революционера-февралиста, показали, как непродуманные преобразования различных «спасителей Отечества» лишь провоцируют очередную смуту в России. Выдающийся русский историк М.М. Богословский заметил, что подобного рода политики из обожаемых публикой демагогов быстро теряют доверие масс, обычно забываются, а то и проклинаются [2, с. 453]. Жаль, что подобные политики способствуют распаду великой державы. 
На рубеже XX-XXI вв. Г.А. Герасименко обратился к методологическим основам дореволюционной российской историографии. На наш взгляд этот поворот объясняется глобальным пересмотром концептуальных воззрений в отечественной исторической науке. Принципы и методы исследований знаменитых российских историков не забывались советскими авторами, которые меняли лишь теоретическое обоснование своих выводов. В связи с этим Г.А. Герасименко надеялся в перспективе преодолеть эти противоречия при дальнейшем изучении многогранной проблематики Великой российской революции. Он издал два учебных пособия по историографии [8] и философским основам российской исторической науки [17]. Расширяя диапазон своих исследований, Григорий Алексеевич одновременно принимал участие в подготовке и издании коллективной монографии о судьбах российских реформ и реформаторов [31]. Он также стал одним из авторов учебника по истории государственного управления в России [18], выдержавшего три издания.

Результаты. Оценивая вклад Г.А. Герасименко в исследование проблематики истории Великой российской революции и разработку теоретико-методологических аспектов исторических изысканий, отметим научную новизну и практическую значимость его трудов на всех этапах деятельности ученого. В Саратове он изучал две проблемы: историю советов Поволжья в 1917-1918 гг. и организацию, структуру, деятельность низовых крестьянских организаций. Научная разработка этих тем отличалась как постановкой исследовательских задач, так и формированием новых концептуальных представлений о расстановке политических сил и причинах победы большевиков в революции. Особо отметим, что публикация в США его монографии о крестьянских комитетах являлась признанием эффективности научной работы историка. Безусловно, эти исследования были ограничены рамками марксистско-ленинской методологии. Однако они и доныне сохраняют свою научную значимость. Автор, вводя в научный оборот огромный пласт массовых архивных источников, так или иначе, начинал по-новому формулировать свои теоретические выводы и наблюдения, которые пока еще были прикрыты флером традиционной научной риторики.

В московский период проблематика исследований Г.А. Герасименко существенно расширилась. В российском научном сообществе периодически возобновлялись дискуссии о предпосылках Великой российской революции. Григорий Алексеевич обратил внимание на ограниченность аргументов авторов в споpax о характере этих причин. В связи с этим он стал изучать крестьянское движение в период реализации столыпинской аграрной реформы и обосновал неизбежность второй социальной войны в деревне. Выясняя роль сельского местного самоуправления, исследователь рассмотрел историю земских учреждений, сформулировав вывод об ограниченности их возможностей в модернизации политического строя России. Эти разработки позволили обобщить весь комплекс составляющих элементов взаимоотношений общественных сил и властных структур в 1917 г., выявить степень детерминированности и иррациональности революционных событий. Обращение историка к специальному рассмотрению генезиса российской государственности, фактического материала истории дореволюционной России способствовало коррекции его теоретико-методологических принципов. Научные труды Г.А. Герасименко стали заметным явлением и сыграли весьма важную позитивную роль в развитии российской историографии, определяя вектор ее развития и новую проблематику исследований.

\section{СПИСОК ЛИТЕРАТУРЫ}

1. Басманов, М. И. Александр Федорович Керенский / М. И. Басманов, Г. А. Герасименко, К. В. Гусев ; под общ. ред. В. А. Динеса. - Саратов : Изд. центр Сарат. гос. экон. акад., 1996. -248 с.

2. Богословский, М. М. Дневники (1913-1919) : Из собрания Государственного исторического музея / М. М. Богословский ; отв. ред. С. О. Шмидт. М. : Время, 2011. - 800 c.

3. Васькин, В. В. Февральская революция в Нижнем Поволжье / В. В. Васькин, Г. А. Герасименко. - Саратов : Изд-во Сарат. ун-та, 1976. $221 \mathrm{c}$.

4. Герасименко, Г. А. Без вины виноватые / Г. А. Герасименко // Литературная газета. 1989 (29 ноября). 
5. Герасименко, Г. А. Борьба крестьян против столыпинской аграрной политики / Г. А. Герасименко. - Саратов : Изд-во Сарат. ун-та, 1985. $342 \mathrm{c}$.

6. Герасименко, Г. А. Возникновение Советов в Нижнем Поволжье (1917 - начало 1918 г.) / Г. А. Герасименко // Саратовский университет. Научная конференция аспирантов и молодых научных сотрудников. Материалы. Вып. 1. Секция истории СССР. - Саратов : Изд-во Сарат. ун-та, 1965. - С. 49-95.

7. Герасименко, Г. А. Земское самоуправление в России / Г. А. Герасименко. - М. : Наука, 1990. -262 c.

8. Герасименко, Г. А. История Российской исторической науки (дооктябрьский период) : учеб. пособие / Г. А. Герасименко. - М. : Советский спорт, 1998. - $192 \mathrm{c}$.

9. Герасименко, Г. А. Народ и власть : 1917 год / Г. А. Герасименко-М. : Воскресенье, 1995. - 288 с.

10. Герасименко, Г. А. Низовые крестьянские организации в 1917 - первой половине 1918 г : На материалах Нижнего Поволжья / Г. А. Герасименко. - Саратов : Изд-во Сарат. ун-та, 1974. -341 с.

11. Герасименко, Г. А. Партийная борьба в Советах Нижнего Поволжья (1917 г.) / Г. А. Герасименко. - Саратов : Изд-во Сарат. ун-та, 1966. - 124 с.

12. Герасименко, Г. А. Первый акт народовластия в России: общественные исполнительные комитеты (1917 г.) / Г. А. Герасименко. - М. : НИКА, 1992. $-349 \mathrm{c}$.

13. Герасименко, Г. А. Победа Октябрьской революции в Саратовской губернии / Г. А. Герасименко. - Саратов : Приволж. кн. изд-во, 1968. - 51 с.

14. Герасименко, Г. А. Советская власть в деревне на первом этапе Октября (на материалах Поволжья) / Г. А. Герасименко, В. П. Семьянинов. Саратов : Изд-во Сарат. ун-та, 1980. - 228 с.

15. Герасименко, Г. А. Советы Нижнего Поволжья в Октябрьской революции / Г. А. Герасименко, Ф. А. Рашитов. - Саратов : Изд-во Сарат. ун-та, 1972. $337 \mathrm{c}$.

16. Герасименко, Г. А. Советы Поволжья в 1917 году : Борьба партий, большевизация Советов, октябрьские дни / Г. А. Герасименко, Д. С. Точеный. - Саратов : Изд-во Сарат. ун-та, 1977. - 324 с.

17. Герасименко, Г. А. Философские основы российской исторической науки. Дооктябрьский период : учеб. пособие / Г. А. Герасименко. - Саратов : Изд-во Сарат. гос. соц.-экон. ун-та, 2002.- 124 с.

18. История государственного управления в России : учебник / Н. Ю. Болотина Н. Ю., Г. А. Герасименко, К. В. Гусев [и др.] ; под общ. ред. Р. Г. Пихои. - 3-е изд., перераб. и доп. - М. : Изд-во РАГС, 2003. -390 c.

19. Кабытов, П. С. Рец. на кн.: Герасименко Г. А. Земское самоуправление в России. - М. : Наука,
1990. - 264 с. / П. С. Кабытов // Вопросы истории. 1991. - № 23. - C. 243-245.

20. Кабытов, П. С. Жизнь и творчество профессора Григория Алексеевича Герасименко / П. С. Кабытов. - Саратов : Техно-Декор, 2016. - 135 с.

21. Кабытов, П. С. Профессор Григорий Алексеевич Герасименко / П. С. Кабытов // Известия Саратовского университета. Новая серия. Серия: История. Международные отношения / под ред. А. И. Авруса, В. Н. Данилова. - Саратов : Изд-во Сарат. ун-та, 2009. - Т. 9. - 27 с.

22. Кабытов, П. С. Профессор Г. А. Герасименко : Саратовский период научной деятельности / П. С. Кабытов // Известия высших учебных заведений. Поволжский регион. Гуманитарные науки. 2007. - № 3. - С. 41-52.

23. Кабытов, П. С. Штрихи к портрету Г. А. Герасименко : Московский период деятельности / П. С. Кабытов // Вестник Самарского государственного университета. - 2007. - № 5-3 (55). - С. 222-231.

24. Кабытов, П. С. Рец. на кн.: Г. А. Герасименко, В. П. Семьянинов. Советская власть в деревне на первом этапе октября (на материалах Поволжья). - Саратов : Изд-во Сарат. ун-та, 1980. 228 с. / П. С. Кабытов // Вопросы истории. - 1982. № 1. - С. 129-131.

25. Кабытова, Н. Н. Земства или советы: российская властная альтернатива в 1917 году / Н. Н. Кабытова // Самарский земский сборник. - Самара : Изд-во Самар. ун-та, 1995. - С. 20-24.

26. Матвеев, М. Н. Драма Волжского земства /М. Н. Матвеев//Новый мир. - 1977. - № 7.-С. 160-174.

27. Мацузато, К. Пересмотр общества тотальной войны: первая мировая война и распад царизма / К. Мацузато // Всеобщая история. - 2017. № 6. - C. 3-19.

28. Октябрь в Поволжье / отв. ред. В. К. Медведев. - Саратов : Приволж. кн. изд-во, 1967. -611 с.

29. Пушкарева, И. М. Рец. на кн.: Герасименко, Г. А. Борьба крестьян против столыпинской аграрной политики / Г. А. Герасименко. - Саратов : Изд-во Сарат. ун-та, 1980. - 228 с. / И. М. Пушкарева // История СССР. - 1988. - № 3. - С. 181-184.

30. Седов, А. В. Рец. на кн.: Герасименко, Г. А. Советская власть в деревне на первом этапе октября (на материалах Поволжья) / Г. А. Герасименко, В. П. Семьянинов. - Саратов : Изд-во Сарат. ун-та, 1980. - 228 с. / А. В. Седов, Э. М. Щагин // История CCCP. - 1982. - № 5. - C. 162-163.

31. Судьбы реформ и реформаторов в России : учеб. пособие / Н. Н. Виноградов [и др.] ; под общ. ред. Р. Г. Пихои, П. Т. Тимофеева. - М. : Изд-во РАГС, 1999. - $372 \mathrm{c}$.

32. Gerasimenko, G. A. Local Organisation in 1917 and the First Half of 1918 / G. A. Gerasimenko // Soviet Studies in History. - 1978. - № 3. - P. 12-129. 
33. Rosenberg, W. The Zemstvo in 1917 and Under the Bolshevic Rule / W. Rosenberg // The Zemstvo in Russia: An Experiment in Local SelfGoverment / ed. by T. Emmons, W. S. Vucinich. - New York : Cambridge University Press, 1982. - P. 402-410.

34. The Zemstvo in Russia: An Experiment in Local Self-Government/ ed. by T. Emmons, W. S. Vucinich. New York : Cambridge University Press, 1982. -452 p.

\section{REFERENCES}

1. Basmanov M.I., Gerasimenko G.A., Gusev K.V. Aleksandr Fedorovich Kerenskii [Alexander Fedorovich Kerensky]. Saratov, Izdftelskii tsentr Saratovskoi gosudarstvennoi ekonomicheskoi akademii, 1996. $248 \mathrm{p}$.

2. Bogoslovskii M.M. Dnevniki (1913-1919): Iz sobraniia Gosudarstvennogo istoricheskogo muzeia [Diaries (1913-1919): From a Meeting of the State Historical Museum]. Moscow, Vremya Publ., $2011.800 \mathrm{p}$.

3. Vaskin V.V., Gerasimenko G.A. Fevralskaia revoliutsiia $v$ Nizhnem Povolzhe [February Revolution in the Lower Volga Region]. Saratov, Izd-vo Saratovskogo universiteta, $1976.221 \mathrm{p}$.

4. Gerasimenko G.A. Bez viny vinovatye [Guilty Without Guilt]. Literaturnaia gazeta [Literary Newspaper], 1989 (November 29).

5. Gerasimenko G.A. Borba krestian protiv stolypinskoi agrarnoi politiki [The Struggle of Peasants Against Stolypin Agrarian Policy]. Saratov, Izd-vo Sarat. un-ta, 1985. 342 p.

6. Gerasimenko G.A. Vozniknovenie Sovetov v Nizhnem Povolzhe (1917-nachalo 1918 g.) [Emergence of Soviets in the Lower Volga Region (1917 - Beginning of 1918)]. Saratovskii universitet. Nauchnaia konferentsiia aspirantov i molodykh nauchnykh sotrudnikov. Materialy. Vyp. 1. Sektsiia istorii SSSR [Saratov University. Scientific Conference of Postgraduate Students and Young Researchers. Materials. Issue. 1. Section of the History of the USSR]. Saratov, Izd-vo Sarat. un-ta, 1965, pp. 49-95.

7. Gerasimenko G.A. Zemskoe samoupravlenie $v$ Rossii [Zemsky Self-Government in Russia]. Moscow, Nauka Publ., 1990. 262 p.

8. Gerasimenko G.A. Istoriia Rossiiskoi istoricheskoi nauki (dooktiabrskii period): ucheb. posobie [History of Russian Historical Science (PreOctober Period). Textbook]. Moscow, Soviet Sport Publ., 1998. 192 p.

9. Gerasimenko G.A. Narod i vlast: 1917 god [People and Power: 1917]. Moscow, Voskresene Publ., $1995.288 \mathrm{p}$.

10. Gerasimenko G.A. Nizovye krestianskie organizatsii v 1917 - pervoi polovine 1918 g.: $\mathrm{Na}$ materialakh Nizhnego Povolzhia [Grassroots Peasant Organizations in 1917 - the First Half of 1918: On the Materials of the Lower Volga Region]. Saratov, Izd-vo Sarat. un-ta, $1974.341 \mathrm{p}$.

11. Gerasimenko G.A. Partiinaia borba $v$ Sovetakh Nizhnego Povolzhia (1917 g.) [Party Struggle in the Councils of the Lower Volga Region (1917)]. Saratov, Izd-vo Sarat. un-ta, 1966. 124 p.

12. Gerasimenko G.A. Pervyi akt narodovlastiia $v$ Rossii: obshchestvennye ispolnitelnye komitety (1917 g.) [The First Act of Peoples Power in Russia: Public Executive Committees (1917)]. Moscow, NIKA Publ., 1992.349 p.

13. Gerasimenko G.A. Pobeda Oktiabrskoi revoliutsii v Saratovskoi gubernii [Victory of the October Revolution in the Saratov Province]. Saratov, Privolzh. kn. izd-vo, 1968. $51 \mathrm{p}$.

14. Gerasimenko G.A., Semianinov V.P. Sovetskaia vlast $v$ derevne na pervom etape Oktiabria (na materialakh Povolzhia) [Soviet Power in the Village at the First Stage of October: (On the Materials of the Volga Region)]. Saratov, Izd-vo Sarat. un-ta, 1980. 228 p.

15. Gerasimenko G.A., Rashitov F.A. Sovety Nizhnego Povolzhia v Oktiabrskoi revoliutsii [Soviets of the Lower Volga Region in the October Revolution]. Saratov, Izd-vo Sarat. un-ta, 1972. $337 \mathrm{p}$.

16. Gerasimenko G.A., Tochenyi D.S. Sovety Povolzhia v 1917 godu: Borba partii, bolshevizatsiia Sovetov, oktiabrskie dni [Soviets of the Volga Region in 1917: Party Struggle, Bolshevization of the Soviets, October Days]. Saratov, Izd-vo Sarat. un-ta, 1977. 324 p.

17. Gerasimenko G.A. Filosofskie osnovy rossiiskoi istoricheskoi nauki. Dooktiabrskii period: ucheb. posobie [Philosophical Foundations of Russian Historical Science. Pre-October Period. Textbook]. Saratov, Izd-vo Sarat. gos. sots.-ekon. un-ta, 2002. $124 \mathrm{p}$.

18. Bolotina N.Iu., Gerasimenko G.A., Gusev K.V. et al. Istoriia gosudarstvennogo upravleniia $v$ Rossii: uchebnik [History of Public Administration in Russia. Study Guide]. Moscow, Izd-vo RAGS, 2003.390 p.

19. Kabytov P.S. Rets. na kn.: Gerasimenko G.A. Zemskoe samoupravlenie v Rossii. Moscow, Nauka Publ., 1990. 264 p. [Book Review. Gerasimenko G.A. Zemsky Self-Government in Russia. Moscow, Nauka Publ., 1990. 264 p.]. Voprosy istorii, 1991, no. 23, pp. 243-245.

20. Kabytov P.S. Zhizn i tvorchestvo professora Grigoriia Alekseevicha Gerasimenko [The Life and Work of Professor Grigory Alekseevich Gerasimenko]. Saratov, Tekhno-Dekor Publ., 2016. 135 p.

21. Kabytov P.S. Professor Grigorii Alekseevich Gerasimenko [Professor Grigory Alekseevich Gerasimenko]. Avrus A.I., Danilov V.N., eds. Izvestiia Saratovskogo universiteta. Novaia seriia. Seriia: Istoriia. Mezhdunarodnye otnosheniia [Izvestiya of 
Saratov University. New Series. Series: History. International Relations]. Saratov, Izd-vo Sarat. un-ta, 2009, vol. 9. 27 p.

22. Kabytov P.S. Professor G.A. Gerasimenko: Saratovskii period nauchnoi deiatelnosti [Professor G.A. Gerasimenko: Saratov Period of Scientific Activity]. Izvestiia vysshikh uchebnykh zavedenii. Povolzhskii region. Gumanitarnye nauki [University Proceedings. Volga Region. Humanities], 2007, no. 3, pp. 41-52.

23. KabytovP.S. Shtrikhi kportretuG.A. Gerasimenko: Moskovskii period deiatelnosti [Shtrikhi to the Portrait of G.A. Gerasimenko: Moscow Period of Activity]. Vestnik Samarskogo gosudarstvennogo universiteta [Vestnik of Samara State University], 2007, no. 5-3 (55), pp. 222-231.

24. Kabytov P.S. Rets. na kn.: G.A. Gerasimenko, V.P. Semyaninov. Sovetskaya vlast' v derevne na pervom etape oktyabrya (na materialakh Povolzh'ya). Saratov, Izd-vo Saratovskogo universiteta, 1980. 228 p. [Book Review. G.A. Gerasimenko, V.P. Semyaninov. Soviet Power in the Village at the First Stage of October (On the Materials of the Volga Region). Saratov, Izd-vo Sarat. un-ta, 1980. 228 p.]. Voprosy istorii, 1982, no. 1, pp. 129-131.

25. Kabytova N.N. Zemstva ili sovety: rossiiskaia vlastnaia alternativa v 1917 godu [Zemstvo or Soviets: Russian Power Alternative in 1917]. Samarskii zemskii sbornik [Samara Zemstvo Herald]. Samara, Izd-vo Sarat. un-ta, 1995, pp. 20-24.

26. Matveev M.N. Drama Volzhskogo zemstvo [Drama of the Volga Zemstvo]. Novyi mir [New World], 1997, no. 7, pp. 160-174.

27. Matsuzato K. Peresmotr obshchestva totalnoi voiny: pervaia mirovaia voina i raspad tsarizma [Revising the Society of Total War: World War I and the Collapse of Tsarism]. Vseobshchaia istoriia [Universal History], 2017, no. 6, pp. 3-19.

28. Medvedev V.K., ed. Oktiabr v Povolzhe [October in the Volga Region]. Saratov, Privolzh. kn. izd-vo, 1967. $611 \mathrm{p}$.

29. Pushkareva I.M. Rets. na kn.: Gerasimenko G.A. Borba krestian protiv stolypinskoi agrarnoi politiki. Saratov, Izd-vo Sarat. un-ta, 1985. 344 p. [Book Review. Gerasimenko G.A. The Struggle of Peasants Against Stolypin's Agrarian Policy. Saratov, Izd-vo Saratovskogo universiteta, 1985. 344 p.]. Istoriia SSSR [SSSR History], 1988, no. 3, pp. 181-184.

30. Sedov A.V. Rets. na kn.: Gerasimenko G.A., Semianinov V.P. Sovetskaia vlast v derevne na pervom etape oktiabria (na materialakh Povolzhia). Saratov, Izdvo Sarat. un-ta, 1980. 228 p. [Book Review. Gerasimenko G.A., Semyaninov V.P. Soviet Power in the Village at the First Stage of October (On the Materials of the Volga Region). Izd-vo Saratovskii universitet, 1980. 228 p.]. Istoriia SSSR [SSSR History], 1982, no. 5, pp. 162-163.

31. Vinogradov N.N. et al. Sudby reform $i$ reformatorov v Rossii: ucheb. posobie [Destinies of Reforms and Reformers in Russia. Textbook]. Moscow, Izd-vo RAGS, 1999. 372 p.

32. Gerasimenko G.A. Local Organisation in 1917 and the First Half of 1918. Soviet Studies in History, 1978, no. 3, pp. 12-129.

33. Rosenberg W. The Zemstvo in 1917 and Under the Bolshevic Rule. Emmons T., Vucinich W.S., eds. The Zemstvo in Russia: An Experiment in Local Self-Goverment. New York, Cambridge University Press, 1982, pp. 402-410.

34. Emmons T., Vucinich W.S., eds. The Zemstvo in Russia: An Experiment in Local Self-Government. New York, Cambridge University Press, 1982. 452 p. 


\section{Information About the Authors}

Petr S. Kabytov, Doctor of Sciences (History), Professor, Honored Science Worker of the Russian Federation, Head of the Department of the Russian History, Samara National Research University, Moskovskoye Shosse, 34, 443086 Samara, Russian Federation, don.kabytov2012@yandex.ru, https://orcid.org/0000-0002-2359-2155

Nadezhda N. Kabytova, Doctor of Sciences (History), Professor, Department of the Russian History, Samara National Research University, Moskovskoye Shosse, 34, 443086 Samara, Russian Federation, don.kabytov2012@yandex.ru, https://orcid.org/0000-0001-9411-8429

Ekaterina P. Barinova, Doctor of Sciences (History), Professor, Department of National History and Historiography, Samara National Research University, Moskovskoye Shosse, 34, 443086 Samara, Russian Federation, rfnz25@yandex.ru, https://orcid.org/0000-0002-2514-9421

\section{Информация об авторах}

Петр Серафимович Кабытов, доктор исторических наук, профессор, заслуженный деятель науки РФ, заведующий кафедрой российской истории, Самарский национальный исследовательский университет им. академика С.П. Королева, ул. Московское шоссе, 34, 443086 г. Самара, Российская Федерация, don.kabytov2012@yandex.ru, https://orcid.org/0000-0002-2359-2155

Надежда Николаевна Кабытова, доктор исторических наук, профессор кафедры российской истории, Самарский национальный исследовательский университет им. академика С.П. Королева, ул. Московское шоссе, 34, 443086 г. Самара, Российская Федерация, don.kabytov2012@yandex.ru, https://orcid.org/0000-0001-9411-8429

Екатерина Петровна Баринова, доктор исторических наук, профессор кафедры отечественной истории и историографии, Самарский национальный исследовательский университет им. академика С.П. Королева, ул. Московское шоссе, 34, 443086 г. Самара, Российская Федерация, rfnz25@yandex.ru, https://orcid.org/0000-0002-2514-9421 